Asian J. Med. Biol. Res. 2016, 2 (3), 442-450; doi: 10.3329/ajmbr.v2i3.30116

\author{
Asian Journal of \\ Medical and Biological Research \\ ISSN 2411-4472 (Print) 2412-5571 (Online) \\ www.ebupress.com/journal/ajmbr
}

\title{
Article \\ Yield and grain dimensions of T. Aman rice varieties as influenced by date of transplanting
}

\author{
Syeda Nuzhat Reza ${ }^{1}$, Nahid Nadia Tani ${ }^{2}$, Muhammad Salim ${ }^{3}$, Ahmed Khairul Hasan ${ }^{4}$ and Mst. Arjina Akter ${ }^{5}$ \\ ${ }^{1}$ Department of Agronomy, Bangladesh Agricultural University, Mymensingh-2202, Bangladesh \\ ${ }^{2}$ Department of Agronomy, Bangladesh Agricultural University, Mymensingh-2202, Bangladesh \\ ${ }^{3}$ Department of Agronomy, Bangladesh Agricultural University, Mymensingh-2202, Bangladesh \\ ${ }^{4}$ Department of Agronomy, Bangladesh Agricultural University, Mymensingh-2202, Bangladesh \\ ${ }^{5}$ Department of Plant Pathology, Bangladesh Agricultural University, Mymensingh-2202, Bangladesh
}

*Corresponding author: Mst. Arjina Akter, Lecturer, Department of Plant Pathology, Faculty of Agriculture, Bangladesh Agricultural University, Mymensingh-2202, Bangladesh. Phone: +8801765478715; Fax: +88-09161510; E-mail: arjinaeva@gmail.com

Received: 07 September 2016/Accepted: 25 September 2016/ Published: 29 September 2016

\begin{abstract}
A field experiment was carried out at the Agronomy Field Laboratory, Bangladesh Agricultural University, Mymensingh, during June 2013 to December 2013 to study the yield and grain dimensions of transplant aman rice varieties as influenced by date of transplanting. The experimental factors comprised of two factors namely, date of transplanting and variety. Date of transplanting comprised of 18 July, 19 August and 18 September. The variety comprised of Binadhan-7, BRRI dhan57, BR11 and Bashiraj. The experimental field was laid out in a split plot design. Most of the yield parameters were significantly affected by the date of transplanting. The yield and yield contributing characters were highest at 19 August transplanting and lowest at 18 September transplanting. Variety had significant effect on most of the yield and yield contributing characters. BR11 gave the highest grain yield $\left(4.47 \mathrm{t} \mathrm{ha}^{-1}\right)$ and the lowest value was obtained in BRRI dhan57. Among the grain dimensions, Binadhan-7 with 18 July transplanting gave the highest grain length $(9.64 \mathrm{~mm})$ whereas BR11 with 18 September transplanting gave the lowest value $(7.82 \mathrm{~mm})$. Results showed that yield components were highest at 19 August transplanting and after that the reduction occurred at 18 September may be due to low temperature and short day length at flowering stage.
\end{abstract}

Keywords: date of transplanting; variety; phenology; yield; grain dimensions.

\section{Introduction}

Bangladesh is an densely populated country and every year nearly 1.94 million people are added to its population of about 152 million (FAO, 2011). Geographical and agronomic conditions of Bangladesh are favourable for rice cultivation. Rice is grown under diverse ecosystems such as irrigated, rainfed and deep water conditions in the three distinct rice growing seasons, namely Aus, Aman and Boro which account for approximately $9 \%, 42 \%$ and $49 \%$ of total annual rice production, respectively (BBS, 2011). Aman rice is one of the main crops in Bangladesh. Presently it is the second largest crop in the country in respect of the volume of production.

The date of transplanting is one of the important factors which affects the grain yield of transplant Aman rice, as in case of early or late planting rice plants may face different types of abiotic stresses. Thus, selection of suitable variety with appropriate planting time may help our farmers to get higher yield. BRRI (1989) and Yoshida (1981) reported that rice plants require a particular temperature for its phenological affair such as panicle initiation; flowering, panicle exertions from flag leaf sheath to maturity and these are very much influenced by the planting dates during T. Aman season. Deviation from the optimum planting time may cause incomplete or 
irregular panicle exsertion and increase spikelet sterility. The optimum planting date as recommended by BRRI is July 15 to August 15 for transplant Aman rice. July transplanting in many cases is not practicable as the land remains occupied by other crops. When these varieties are transplanted in the late season during SeptemberOctober, their sensitivity of flowering in the months of November-December mostly depends on the planting dates. The late transplanting exposes the reproductive phase as well as phenological events of crop is very much sensitive to day length and lower temperature regime, thereby, causing high spikelet sterility and poor growth of the plant and finally reduction of grain yield through the reduction of yield contributing characters. The yield contributing characters specially number of effective tillers hill ${ }^{-1}$, number of grains panicle $^{-1}$, grain yield and straw yield were significantly affected when compared to late transplanting. Many of them obtained better results from early transplanting than late transplanting (Darko et al., 2013; Ali et al., 2012; Tamanna, 2007; Pandey et al., 2001).

Rice grain width and shape play important role in determining grain yield (Lin and $\mathrm{Wu}, 2003$ ). Rice grain appearance is mainly specified by grain shape as defined by grain length, width and the length-width ratio (LWR) (Zhang, 2007).The great economic importance associated with grain width and shape necessitates indepth study of their genetic basis and development mechanisms to better understand biological development processes and to facilitate breeding in rice. Some of the genotypes showed significant variation in response to sowing dates in terms of grain length. In contrast, grain weight of most varieties was not significantly affected by different transplanting dates. The length to width ratio (LWR) of most of the genotypes was highest under late sowing compared to early and mid sowing (Zhu et al., 2013).

Bangladesh Rice Research Institute (BRRI) and Bangladesh Institute of Nuclear Agriculture (BINA) have developed some HYVs and works on their photosensitivity. Experiments on date of transplanting are the most effective means to identify the photosensitivity. In a view of above discussion the present study was designed and carried out with to evaluate the yield components and grain dimensions of T. Aman rice varieties. To find out the effect of date of transplanting on the yield, yield component and grain dimensions of T. Aman rice varieties. To find out the interaction, if any, between date of transplanting and variety on the yield, yield components and grain dimensions of T. Aman rice.

\section{Materials and Methods}

\subsection{Location}

The experiment was carried out at the Agronomy Field Laboratory, Bangladesh Agricultural University, Mymensingh during the period from July to December 2013. The experiment field was located at $24^{0} 75^{\prime} \mathrm{N}$ latitude and $90^{\circ} 50^{\prime} \mathrm{E}$ longitude having an altitude of $18 \mathrm{~m}$ above the mean sea level. The experimental site belongs to the Sonatola soil series, having calcareous dark grey soil under Agro-ecological Zone of the Old Brahmaputra Floodplain (AEZ-9).

\subsection{Soil}

The experimental field was medium high land with moderate drained condition. The land was silty loam in texture having a soil $\mathrm{pH}$ value of 6.5 , low in organic matter content and its general fertility level was also low.

\subsection{Climate}

The experimental area was located under the sub-tropical climate which is specialized by moderately high temperature and heavy rainfall during the Kharif season (April-September) and low rainfall with moderately low temperature during Rabi season (October-March). In 2013, monthly average highest air temperature $\left(29.8^{0} \mathrm{c}\right)$ was recorded in June and lowest $\left(19.8^{\circ} \mathrm{c}\right)$ was recorded in December, the highest rainfall $(338.8 \mathrm{~mm})$ was recorded in July and lowest $(0.0 \mathrm{~mm})$ was measured in November.

\subsection{Experimental Treatments}

The experimental factors comprised of two factors namely, date of transplanting and variety. Date of transplanting comprised of 18 July, 19 August and 18 September. The variety comprised of Binadhan-7, BRRI dhan57, BR11 and Bashiraj.

\subsection{Experimental design and layout}

The experimental field was laid out in a split plot design. The date of transplanting were assigned in the main plots and varieties in the subplot. The total numbers of unit plots were 36 . The area of each unit plot was $2.5 \mathrm{~m} \times 2.0 \mathrm{~m}(5$ sq. $\mathrm{m})$. 
2.6. Seed collection

Healthy and vigorous Seeds of BRRI dhan57, Bashiraj, BR11 were collected from Agronomy Field Laboratory, Bangladesh Agricultural University, Mymensingh. Healthy seeds of Binadhan-7 were collected from the BINA, Mymensingh.

\subsection{Seed sprouting}

Healthy seeds of the variety were selected by specific gravity method. The selected seeds were soaked in water for 24 hours and then they were taken out and placed in gunny bags for sprouting. The seeds started sprouting after 48 hours and were suitable for sowing after 72 hours.

\subsection{Fertilizer application}

All the fertilizers (Triple Super Phosphate, Muriate of Potash, Zypsum and Zinc sulphate) accept urea were applied during the final land preparation. Nitrogen was applied in three splits. The $1^{\text {st }}$ one-third was applied at 20 DAT as top dressing, the $2^{\text {nd }}$ one-third was applied during early tillering stage (30-35 DAT) and last onethird applied at panicle initiation stage (50-55 DAT) as top dressing.

\subsection{Transplanting of seedling}

35 day old seedlings were uprooted carefully from the nursery bed of Agronomy Field Laboratory, BAU, Mymensingh. Before uprooting the seedlings, nursery beds were slightly irrigated for easier uprooting. Uprooted seedlings were transplanted in the unit plots on 3 different dates in 18 July, 19 August and 18 September 2013, respectively. Three seedlings were transplanted in each hill maintaining a spacing of $25 \mathrm{~cm} \times 15 \mathrm{~cm}$.

\subsection{Intercultural operations}

Intercultural operations such as weeding, gap filling and irrigation were done in order to ensure and maintain the normal growth of the crop as and when necessary. No protection measures were taken during the experimental period.

\subsection{Procedure of data collection}

During the growth period phonological data viz. date of tillering, panicle initiation (PI), booting, heading, flowering, grain filled duration, physiological maturity (PM) and total field duration were recorded. When 90\% of grain became golden yellow in colour, five hills (excluding border hills) were randomly selected from each unit plot according to the treatments for collecting the yield parameters. Data on individual plant parameters were recorded from five randomly selected hills of each plot and those on number of panicles $\mathrm{m}^{-2}$, number of grains $\mathrm{m}^{-2}, 1000$-grain weight, grain yield, straw yield, harvest index were recorded $1 \mathrm{~m}^{2}$ area of plot at harvest. Length, width, and height (grain dimensions) of randomly selected twenty grains were measured with a digital caliper. The grain weight of twenty grains was measured by digital grain moisture meter and grain volume was calculated. Grain volume (GV) was calculated from these measurements assuming the grains as an ellipsoid according to the Piskunov equation (1978) as in a previous studies (Miralles et al. 1998; Hasan et al. 2011) respectively.

Grain volume $=4 / 3 \pi$ a b c

Where: $\pi=3.1416, \mathrm{a}=0.5$ length, $\mathrm{b}=0.5$ width (lateral width) and $\mathrm{c}=0.5$ height (dorsal) of the grain. The accuracy of this procedure was demonstrated by Hasan et al. 2011. Individual grain weight in each plot of randomly selected twenty grains was measured by digital grain moisture meter.

All the data were analyzed statistically and mean differences were adjusted by DMRT.

\section{Results and Discussion}

\subsection{Phenological events}

From table 1 it was found that duration of early tillering (ET), panicle initiation (PI), booting, heading, anthesis, physiological maturity (PM), grain filling duration and total field duration was gradually decreased with delayed transplanting up to September 18th. Among the varieties, BR11 and Bashiraj took more days to reach physiological maturity while BRRI dhan57 and Binadhan-7 reached earlier. The highest duration was found in Bashiraj at the most of the transplanting dates and lowest one was found in BRRI dhan57.

From the climatic data it was found that early transplanted crop received more favourable day length, temperature, sunlight especially at the time of tillering, anthesis and grain filling compared to the late transplanting. It was clear that early transplanting dates were less sensitive for day length and photoperiod phase 
but 18 September transplanted crops were suffered most by the low temperature and during the grain filling time. These data were in agreement with Ali et al., (2012) who found that duration of maximum tillering, panicle initiation, flowering stage were gradually decreased in T. Aman rice with delayed transplanting.

\subsection{Yield parameters}

All the yield parameters was significantly affected by date of transplanting except unfilled grain panicle ${ }^{-1}, 1000$ grain weight and harvest index. Among the transplanting dates 19 August transplanting gave the highest yield parameters viz. effective tillers hill $^{-1}(10.95)$, number of grains panicle ${ }^{-1}(96.19)$, sterile spikelets panicle ${ }^{-1}$ (12.83), number of panicle $\mathrm{m}^{-2}$ (254.83) number of grains $\mathrm{m}^{-2}$ (22622.88), 1000 grain weight (20.74g), grain yield $\left(4.65 \mathrm{t} \mathrm{ha}^{-1}\right)$, straw yield $\left(5.71 \mathrm{t} \mathrm{ha}^{-1}\right)$, biological yield $\left(10.36 \mathrm{t} \mathrm{ha}^{-1}\right)$, harvest index $(44.81 \%)$ except plant height and panicle length. Plant height $(118.68 \mathrm{~cm})$ and panicle length $(22.52 \mathrm{~cm})$ was highest at $18 \mathrm{July}$ transplanting, where as 18 September produced the lowest above mentioned parameters (Table 2). The19 August gave $40 \%$ higher yield than 18 September transplanting. For late transplanting, low temperature, short day length at the pollen development stage may cause a sharp decline in fertile or filled spikelet particularly in the photo sensitive cultivars. Thus, for late transplanting, poor pollen germination may be another reason for decline in yield. The higher yield for early transplanting may be due to favourable climatic conditions especially at the time of tillering, flowering and grain filling. Early transplanted crops received more favourable day length, temperature, sunlight especially at the tillering stage and panicle initiation stages compared to later transplanted crops. The similar data also reported by Darko et al. (2013) who found that the best yield of $5.99 \mathrm{t} \mathrm{ha}^{-1}$ would be achieved when planting is done on August 1st sowing. Tamanna (2007) found that grain yield significantly decreased with delay transplanting, the yield decreasing by $50 \%$ when transplanting was delayed to 25 September.

Variety was significantly affected all the yield parameters at $1 \%$ level of probability, except the harvest index. From Table 3 Among the varieties BR11 produced the highest number of grains panicle ${ }^{-1}$ (78.53), panicle weight $(80.09 \mathrm{~g}), 1000$ grain weight $(23.25 \mathrm{~g})$, grain yield $\left(4.47 \mathrm{t} \mathrm{ha}^{-1}\right)$, straw yield $\left(5.48 \mathrm{t} \mathrm{ha}^{-1}\right)$ and harvest index $(44.71 \%)$. Plant height $(137.00 \mathrm{~cm})$, effective tillers hill ${ }^{-1}(11.07)$, panicle length $(22.36 \mathrm{~cm})$, number of grains $\mathrm{m}^{-2}$ (23469.90) and number of panicles $\mathrm{m}^{-2}(281.78)$ was highest in Bashiraj where as BRRI dhan57 produced the lowest above mentioned parameters except the number of grains $\mathrm{m}^{-2}$. The lowest number of grains $\mathrm{m}^{-2}$ (15177.03) was produced by Binadhan-7. The results indicated that BR11 produced the highest grain yield and it gave $28.41 \%$ more yield than BRRI dhan57, because it is a high yielding varieties which have been developed by BRRI and was statistically similar with Bashiraj $\left(4.25 \mathrm{t} \mathrm{ha}^{-1}\right)$. The probable reason of the different grain yield due to the different yield parameters (no of tiller, no of grain panicle ${ }^{-1}$, filled grain panicle ${ }^{-1}, 1000$ grain weight etc.) influenced by the genetic make-up of the variety.

Yield differences due to varieties were recorded by Saha (2013), Anjuman (2012) and Khisha (2002), who observed variable grain yield among varieties.

From Table 4 we found that the interaction of date of transplanting and variety was significantly affected all the yield parameters at $1 \%$ level of probability except harvest index. Highest plant height $(161.23 \mathrm{~cm})$ was obtained from the interaction of 18 July $\times$ Bashiraj, which was statistically identical with the interaction of 19 August $\times$ Bashiraj and lowest was found in BRRI dhan57 $(57.13 \mathrm{~cm})$ transplanted at 18 September, which was statistically identical with the interaction of 18 September $\times$ BR11 and 18 September $\times$ Binadhan-7. The highest number of effective tillers hill ${ }^{-1}$ (13.60) was produced in the interaction of 19 August $\times$ BR11, which was statistically identical with the interaction of 18 July $\times$ Bashiraj. The lowest number was found in the interaction of 18 September $\times$ BRRI dhan57. The highest grains panicle ${ }^{-1}$ (123.13), panicle weight (105.38g), 1000 grain weight $(23.26 \mathrm{~g})$, grain yield $\left(5.58 \mathrm{t} \mathrm{ha}^{-1}\right)$, straw yield $\left(6.69 \mathrm{t} \mathrm{ha}^{-1}\right)$ and harvest index $(45.49 \%)$ was found in the interaction of 19 August $\times$ BR11. The highest number of panicles $\mathrm{m}^{-2}$ (306.00) and number of grains $\mathrm{m}^{-2}$ (25972.81) was found in the interaction of 19 August $\times$ Bashiraj and 18 July $\times$ Bashiraj. The lowest number of panicles $\mathrm{m}^{-2}(143.00), 1000$ grain weight $(16.44 \mathrm{~g})$, grain yield $\left(2.42 \mathrm{t} \mathrm{ha}^{-1}\right)$, straw yield $\left(3.12 \mathrm{t} \mathrm{ha}^{-1}\right)$ and harvest index $(43.75 \%)$ was found in the interaction of 18 September $\times$ BRRI dhan57. Interaction of 18 September $\times$ BR11 produced lowest number of grains panicle ${ }^{-1}(29.98)$ and number of grains $\mathrm{m}^{-2}(10562.13)$. 
Table 1. Date of occurrence of early tillering (ET), panicle initiation (PI), booting (Bo), heading, anthesis (Anth), physiological maturity (PM), grain filling duration and total field duration of some T. Aman rice under different date of transplanting.

\begin{tabular}{|c|c|c|c|c|c|c|c|c|c|c|c|c|c|c|c|c|c|}
\hline \multirow{2}{*}{$\begin{array}{l}\text { Date of } \\
\text { transplanting }\end{array}$} & \multirow[t]{2}{*}{ Variety } & \multicolumn{6}{|c|}{ Each stage was calculated from days after transplanting } & \multirow{2}{*}{$\begin{array}{l}\text { ET-Bo } \\
\text { Duration } \\
\text { (Days) }\end{array}$} & \multirow{2}{*}{$\begin{array}{c}\text { ET-Bo } \\
\text { * Sun } \\
\text { Shine } \\
(\mathrm{hrs})\end{array}$} & \multirow{2}{*}{$\begin{array}{l}\text { ET-Bo } \\
\text { Temp } \\
\text { (Mean) }\end{array}$} & \multirow{2}{*}{$\begin{array}{l}\text { Bo-At } \\
\text { Duration } \\
\text { (Days) }\end{array}$} & \multirow{2}{*}{$\begin{array}{c}\text { Bo-At } \\
\text { Sun } \\
\text { Shine } \\
\text { (hrs) }\end{array}$} & \multirow{2}{*}{$\begin{array}{l}\text { Bo-At } \\
\text { Temp } \\
\text { (Mean) }\end{array}$} & \multirow{2}{*}{$\begin{array}{l}\text { At-PM } \\
\text { Duration } \\
\text { (Days) }\end{array}$} & \multirow{2}{*}{$\begin{array}{l}\text { At-PM } \\
\text { *Sun } \\
\text { Shine } \\
(\text { hrs })\end{array}$} & \multirow{2}{*}{$\begin{array}{c}\text { At-PM } \\
\text { Temp } \\
\text { (Mean) }\end{array}$} & \multirow{2}{*}{$\begin{array}{l}\text { Total } \\
\text { Field } \\
\text { Duration }\end{array}$} \\
\hline & & $\begin{array}{l}\text { Early } \\
\text { tillering } \\
\text { (ET) }\end{array}$ & $\begin{array}{l}\text { Panicle } \\
\text { Initiation } \\
(\mathrm{PI})\end{array}$ & $\begin{array}{l}\text { Bootin } \\
\text { (Bo) }\end{array}$ & g Heading & $\begin{array}{l}\text { Anthesis } \\
\text { (At) }\end{array}$ & $\begin{array}{l}\text { Physiological } \\
\text { Maturity } \\
\text { (PM) }\end{array}$ & & & & & & & & & & \\
\hline $\mathrm{T}_{1}$ & $\mathrm{~V}_{1}$ & 30 & 46 & 52 & 56 & 62 & 83 & 22 & 3.61 & 29.18 & 10 & 6.7 & 29.6 & 21 & 4.83 & 28.41 & 118 \\
\hline $\mathrm{T}_{1}$ & $\mathrm{~V}_{2}$ & 22 & 48 & 55 & 60 & 68 & 96 & 33 & 3.62 & 29.05 & 13 & 6.48 & 29.97 & 28 & 4.67 & 27.69 & 131 \\
\hline $\mathrm{T}_{1}$ & $\mathrm{~V}_{3}$ & 35 & 58 & 74 & 80 & 90 & 110 & 39 & 4.23 & 29.29 & 16 & 5.57 & 27.78 & 20 & 4.69 & 25.92 & 145 \\
\hline $\mathrm{T}_{1}$ & $\mathrm{~V}_{4}$ & 39 & 66 & 90 & 101 & 107 & 139 & 51 & 4.55 & 28.73 & 17 & 4.32 & 26.29 & 32 & 7.61 & 22.9 & 174 \\
\hline $\mathrm{T}_{2}$ & $\mathrm{~V}_{1}$ & 25 & 37 & 48 & 55 & 64 & 91 & 23 & 4.59 & 28.77 & 16 & 5.67 & 27.59 & 27 & 6.09 & 24.47 & 126 \\
\hline $\mathrm{T}_{2}$ & $\mathrm{~V}_{2}$ & 20 & 31 & 36 & 40 & 48 & 79 & 16 & 6.50 & 30.04 & 12 & 2.67 & 27.87 & 31 & 5.02 & 26.43 & 114 \\
\hline $\mathrm{T}_{2}$ & $\mathrm{~V}_{3}$ & 28 & 53 & 63 & 72 & 78 & 107 & 35 & 5.20 & 28.45 & 15 & 4.36 & 25.26 & 29 & 7.99 & 22.71 & 142 \\
\hline $\mathrm{T}_{2}$ & $\mathrm{~V}_{4}$ & 31 & 55 & 63 & 70 & 80 & 112 & 32 & 4.99 & 28.33 & 17 & 4.80 & 25.12 & 32 & 7.68 & 22.54 & 147 \\
\hline $\mathrm{T}_{3}$ & $\mathrm{~V}_{1}$ & 20 & 33 & 52 & 60 & 68 & 90 & 32 & 5.26 & 26.32 & 16 & 8.28 & 22.63 & 22 & 5.43 & 21.09 & 125 \\
\hline $\mathrm{T}_{3}$ & $\mathrm{~V}_{2}$ & 15 & 28 & 37 & 44 & 52 & 83 & 22 & 5.16 & 27.51 & 15 & 4.71 & 24.73 & 31 & 7.64 & 22.44 & 118 \\
\hline $\mathrm{T}_{3}$ & $\mathrm{~V}_{3}$ & 25 & 37 & 59 & 64 & 72 & 102 & 34 & 5.69 & 25.58 & 13 & 7.69 & 21.89 & 30 & 3.46 & 19.8 & 137 \\
\hline $\mathrm{T}_{3}$ & $\mathrm{~V}_{4}$ & 22 & 35 & 43 & 48 & 56 & 85 & 21 & 4.65 & 26.73 & 13 & 8.05 & 23.77 & 29 & 6.07 & 21.26 & 120 \\
\hline
\end{tabular}

Here, $\mathrm{T}_{1}=18$ July, $\mathrm{T}_{2}=19$ August, $\mathrm{T}_{3}=18$ September.

$\mathrm{V}_{1}=$ Binadhan-7, $\mathrm{V}_{2}=$ BRRI dhan57, $\mathrm{V}_{3}=\mathrm{BR} 11, \mathrm{~V}_{4}=$ Bashiraj.

Table 2. Effect of date of transplanting on yield and yield components of T. Aman rice.

\begin{tabular}{|c|c|c|c|c|c|c|c|c|c|c|c|c|}
\hline $\begin{array}{l}\text { Date of } \\
\text { transplanting }\end{array}$ & $\begin{array}{l}\text { Plant } \\
\text { height }(\mathrm{cm})\end{array}$ & $\begin{array}{l}\text { No. of } \\
\text { effective } \\
\text { tillers hill' }\end{array}$ & $\begin{array}{l}\text { No. of non- } \\
\text { effective } \\
\text { tillers hill }^{-1}\end{array}$ & $\begin{array}{l}\text { No. of } \\
\text { grains } \\
\text { panicle }^{-1}\end{array}$ & $\begin{array}{l}\text { No. of sterile } \\
\text { spikelets } \\
\text { panicle }^{-1}\end{array}$ & $\begin{array}{l}\text { No. of } \\
\text { panicles } \mathbf{m}^{-2}\end{array}$ & $\begin{array}{l}\text { No. of } \\
\text { grains } \\
\text { m }^{-2}\end{array}$ & $\begin{array}{l}\text { Panicle } \\
\text { weight (g) }\end{array}$ & $\begin{array}{l}\text { 1000-grain } \\
\text { weight (g) }\end{array}$ & $\begin{array}{l}\text { Grain } \\
\text { yield } \\
\left(\mathrm{t} \mathrm{ha}^{-1}\right)\end{array}$ & $\begin{array}{l}\text { Straw } \\
\text { yield } \\
\left(\text { t ha }^{-1}\right)\end{array}$ & $\begin{array}{l}\text { Harvest } \\
\text { index }(\%)\end{array}$ \\
\hline$\overline{T_{1}}$ & $118.68 \mathrm{a}$ & $10.55 \mathrm{a}$ & 1.53 & $77.62 b$ & $12.75 b$ & $247.25 b$ & $19725.22 b$ & $89.03 a$ & $20.56 a$ & $4.00 \mathrm{ab}$ & $4.96 \mathrm{ab}$ & $44.63 \mathrm{ab}$ \\
\hline $\mathbf{T}_{2}$ & $110.38 b$ & $10.95 \mathrm{a}$ & 2.08 & $96.19 \mathrm{a}$ & $12.83 b$ & $254.83 \mathrm{a}$ & $22622.88 \mathrm{a}$ & $89.84 \mathrm{a}$ & $20.74 a$ & $4.65 \mathrm{a}$ & $5.71 \mathrm{a}$ & $44.81 \mathrm{a}$ \\
\hline $\mathbf{T}_{3}$ & $70.19 \mathrm{c}$ & $8.78 b$ & 1.95 & $50.70 \mathrm{c}$ & $13.59 \mathrm{a}$ & $212.00 \mathrm{c}$ & $14678.56 \mathrm{c}$ & $39.59 b$ & $19.51 \mathrm{~b}$ & $2.79 b$ & $3.53 b$ & $44.13 b$ \\
\hline$\overline{\mathrm{CV}(\%)}$ & 2.51 & 6.07 & 3.56 & 6.85 & 13.00 & 2.75 & 13.88 & 5.05 & 2.89 & 3.48 & 4.51 & 3.56 \\
\hline Level of sig & $* *$ & * & NS & $* *$ & $*$ & $*$ & $* *$ & $* *$ & $* *$ & $* *$ & $* *$ & $*$ \\
\hline
\end{tabular}

In a column figures with similar letters or without letters do not differ significantly whereas figures with dissimilar letter differ significantly as per DMRT.

NS $*$ and $* *$ indicates not significant, significant at $5 \%$ and $1 \%$ level of probability.

$\mathrm{T}_{1}=18$ July, $\mathrm{T}_{2}=19$ August, $\mathrm{T}_{3}=18$ September. 
Table 3. Effect of variety on yield and yield components of T. Aman rice.

\begin{tabular}{|c|c|c|c|c|c|c|c|c|c|c|c|c|}
\hline Variety & $\begin{array}{l}\text { Plant } \\
\text { height } \\
\text { (cm) }\end{array}$ & $\begin{array}{l}\text { No. of } \\
\text { effective } \\
\text { tillers } \\
\text { hill }^{-1}\end{array}$ & $\begin{array}{l}\text { No. of non- } \\
\text { effective } \\
\text { tillers } \\
\text { hill }^{-1}\end{array}$ & $\begin{array}{l}\text { No. of } \\
\text { grains } \\
\text { panicle }^{-1}\end{array}$ & $\begin{array}{l}\text { No. of } \\
\text { sterile } \\
\text { spikelets } \\
\text { panicle }^{-1}\end{array}$ & $\begin{array}{l}\text { No. of } \\
\text { panicles } \mathbf{m}^{-2}\end{array}$ & $\begin{array}{l}\text { No. of grains } \\
\mathrm{m}^{-2}\end{array}$ & $\begin{array}{l}\text { Panicle } \\
\text { weight (g) }\end{array}$ & $\begin{array}{l}\text { 1000-grain } \\
\text { weight (g) }\end{array}$ & $\begin{array}{l}\text { Grain } \\
\text { yield } \\
\left(\mathrm{t} \mathrm{ha}^{-1}\right)\end{array}$ & $\begin{array}{l}\text { Straw } \\
\text { yield } \\
\left(t_{\text {ha }}^{-1}\right)\end{array}$ & $\begin{array}{l}\text { Harvest } \\
\text { index }(\%)\end{array}$ \\
\hline$\overline{V_{1}}$ & $87.05 c$ & $9.87 b$ & $2.62 a$ & $72.23 \mathrm{c}$ & $15.12 \mathrm{a}$ & $232.33 c$ & $15177.03 \mathrm{~d}$ & $76.34 b$ & $21.92 b$ & $3.33 b$ & $4.15 b$ & 44.54 \\
\hline $\mathbf{V}_{2}$ & $81.07 \mathrm{~d}$ & $8.53 c$ & $1.29 b$ & $72.06 \mathrm{c}$ & $10.59 \mathrm{~d}$ & $196.22 d$ & $18047.70 \mathrm{c}$ & $62.93 \mathrm{~d}$ & $17.77 \mathrm{~d}$ & $3.20 \mathrm{~b}$ & $4.02 \mathrm{~b}$ & 44.24 \\
\hline $\mathbf{V}_{3}$ & $93.88 b$ & $10.91 \mathrm{ab}$ & $1.71 \mathrm{ab}$ & $78.53 a$ & $12.27 \mathrm{c}$ & $241.78 b$ & $19340.91 b$ & $80.09 a$ & $23.25 \mathrm{a}$ & $4.47 \mathrm{a}$ & $5.48 \mathrm{a}$ & 44.71 \\
\hline $\mathbf{V}_{4}$ & $137.00 \mathrm{a}$ & $11.07 \mathrm{a}$ & 1.80 & $76.53 b$ & $14.24 \mathrm{~b}$ & $281.78 \mathrm{a}$ & $23469.90 a$ & $71.93 \mathrm{c}$ & $18.12 \mathrm{c}$ & $4.25 \mathrm{ab}$ & $5.28 \mathrm{ab}$ & 44.59 \\
\hline CV (\%) & 2.51 & 6.07 & 3.56 & 6.85 & 13.00 & 2.75 & 13.88 & 5.05 & 2.89 & 3.48 & 4.51 & 3.56 \\
\hline Level of sig & $* *$ & $* *$ & $* *$ & $* *$ & $* *$ & $* *$ & $* *$ & $* *$ & $* *$ & $* *$ & $* *$ & NS \\
\hline
\end{tabular}

In a column figures with similar letters or without letters do not differ significantly whereas figures with dissimilar letter differ significantly as per DMRT.

NS and $* *$ indicates not significant and significant at $1 \%$ level of probability.

$\mathrm{V}_{1}=$ Binadhan $-7, \mathrm{~V}_{2}=$ BRRI dhan57, $\mathrm{V}_{3}=\mathrm{BR} 11, \mathrm{~V}_{4}=$ Bashiraj.

Table 4. Effect of interaction of date of transplanting and variety on yield and yield components of T. Aman rice

\begin{tabular}{|c|c|c|c|c|c|c|c|c|}
\hline $\begin{array}{l}\text { Date of transplanting } \\
\times \text { variety }\end{array}$ & $\begin{array}{l}\text { Plant height } \\
\text { (cm) }\end{array}$ & $\begin{array}{l}\text { No. of } \\
\text { effective } \\
\text { tillers } \\
\text { hill }^{-1} \\
\end{array}$ & $\begin{array}{l}\text { No. of non- } \\
\text { effective tillers } \\
\text { hill }^{-1}\end{array}$ & $\begin{array}{l}\text { No. of } \\
\text { grains panicle }^{-1}\end{array}$ & $\begin{array}{l}\text { No. of sterile } \\
\text { spikelets panicle- } \\
1\end{array}$ & $\begin{array}{l}\text { No. of panicles } \\
\mathrm{m}^{-2}\end{array}$ & $\begin{array}{l}\text { 1000-grain } \\
\text { weight }(g)\end{array}$ & $\begin{array}{l}\text { Harvest index } \\
(\%)\end{array}$ \\
\hline $\mathbf{T}_{1} \mathbf{V}_{1}$ & $106.47 b c$ & $10.20 \mathrm{~b}$ & $2.60 \mathrm{bc}$ & $73.87 \mathrm{cde}$ & $15.58 \mathrm{ab}$ & 228.33 cde & $22.69 a$ & 44.68 \\
\hline $\mathbf{T}_{1} \mathbf{V}_{2}$ & $96.93 \mathrm{~cd}$ & $8.33 \mathrm{bc}$ & $0.87 f g$ & $84.55 \mathrm{bcd}$ & $10.02 \mathrm{fg}$ & $201.33 \mathrm{e}$ & $19.42 b$ & 44.31 \\
\hline $\mathbf{T}_{1} \mathbf{V}_{3}$ & $110.07 \mathrm{~b}$ & $10.33 b$ & $1.20 \mathrm{efg}$ & $82.48 \mathrm{bcd}$ & $12.16 \mathrm{c}-\mathrm{f}$ & $253.33 \mathrm{bcd}$ & $22.79 a$ & 44.77 \\
\hline $\mathbf{T}_{1} \mathbf{V}_{4}$ & $161.23 \mathrm{a}$ & $13.33 \mathrm{a}$ & $1.47 \mathrm{def}$ & 69.58def & $13.14 b-e$ & $306.00 \mathrm{a}$ & $17.33 \mathrm{~cd}$ & 44.75 \\
\hline $\mathbf{T}_{2} \mathrm{~V}_{1}$ & $91.27 d$ & $9.60 \mathrm{~b}$ & 1.40def & $86.49 \mathrm{bc}$ & $11.06 \mathrm{efg}$ & 242.67b-e & $23.04 \mathrm{a}$ & 44.49 \\
\hline $\mathbf{T}_{2} \mathbf{V}_{2}$ & $89.13 d$ & $10.20 \mathrm{~b}$ & $2.73 b$ & 80.91 bced & $11.87 \mathrm{~d}-\mathrm{g}$ & $244.33 \mathrm{bcd}$ & $17.46 \mathrm{~cd}$ & 44.66 \\
\hline $\mathbf{T}_{2} \mathbf{V}_{3}$ & $108.20 \mathrm{~b}$ & $13.60 \mathrm{a}$ & $2.40 \mathrm{bcd}$ & $123.13 \mathrm{a}$ & $14.73 \mathrm{bcd}$ & $259.33 b c$ & $23.26 \mathrm{a}$ & 45.49 \\
\hline $\mathbf{T}_{2} \mathrm{~V}_{4}$ & $152.90 \mathrm{a}$ & $10.40 \mathrm{~b}$ & $1.80 \mathrm{~b}-\mathrm{f}$ & $94.23 b$ & $13.65 b-f$ & $273.00 \mathrm{ab}$ & $19.18 b$ & 44.58 \\
\hline $\mathbf{T}_{3} \mathbf{V}_{1}$ & $63.40 \mathrm{e}$ & $9.80 \mathrm{~b}$ & $3.87 \mathrm{a}$ & $56.33 \mathrm{fg}$ & $18.62 \mathrm{a}$ & $226.00 \mathrm{cde}$ & $20.04 b$ & 44.45 \\
\hline $\mathbf{T}_{3} \mathbf{V}_{2}$ & $57.13 \mathrm{e}$ & $7.07 \mathrm{c}$ & $0.27 \mathrm{~g}$ & $50.72 \mathrm{~g}$ & $9.87 \mathrm{~g}$ & $143.00 \mathrm{f}$ & $16.44 d$ & 43.75 \\
\hline $\mathbf{T}_{3} \mathbf{V}_{3}$ & $63.37 \mathrm{e}$ & $8.80 \mathrm{bc}$ & $1.53 \mathrm{c}-\mathrm{f}$ & $29.98 \mathrm{~h}$ & $9.92 \mathrm{~g}$ & $212.67 \mathrm{de}$ & $23.71 \mathrm{a}$ & 43.86 \\
\hline $\mathbf{T}_{3} \mathbf{V}_{4}$ & $96.87 \mathrm{~cd}$ & $9.47 \mathrm{bc}$ & $2.13 b-e$ & $65.77 \mathrm{ef}$ & $15.94 \mathrm{abc}$ & $266.33 b c$ & $17.85 \mathrm{c}$ & 44.45 \\
\hline CV (\%) & 2.51 & 6.07 & 3.56 & 6.85 & 13.00 & 2.75 & 2.89 & 3.56 \\
\hline Level of sig & $* *$ & $* *$ & $* *$ & $* *$ & $* *$ & $* *$ & $* *$ & NS \\
\hline
\end{tabular}

In a column figures with similar letters or without letters do not differ significantly whereas figures with dissimilar letter differ significantly as per DMRT. NS and $* *$ indicates not significant and significant at $1 \%$ level of probability.

$\mathrm{T}_{1}=18$ July, $\mathrm{T}_{2}=19$ August, $\mathrm{T}_{3}=18$ September. $\quad \mathrm{V}_{1}=$ Binadhan $-7, \mathrm{~V}_{2}=$ BRRI dhan57, $\mathrm{V}_{3}=\mathrm{BR} 11, \mathrm{~V}_{4}=\mathrm{Bashiraj}$ 
3.3. Relationship between total biomass and grain yield

Relationship between grain yield and total biomass has been shown in (Figure 1). Total dry biomass is an important character responsible for higher yield. Experimental results revealed that the grain yield showed significantly positive correlation $\left(\mathrm{R}^{2}=0.98^{* *}\right)$ with total dry biomass (Figure 1). This means an increase in total biomass resulted in the corresponding increased in the grain yield of transplant Aman rice. Thus indicate total biomass might be critical characteristics in yield performance of transplant Aman rice. From the results discussed above, it can be concluded that transplant Aman rice cv. BR11 grown at 19 August emerged out as a promising practice to achieve desired grain yield.

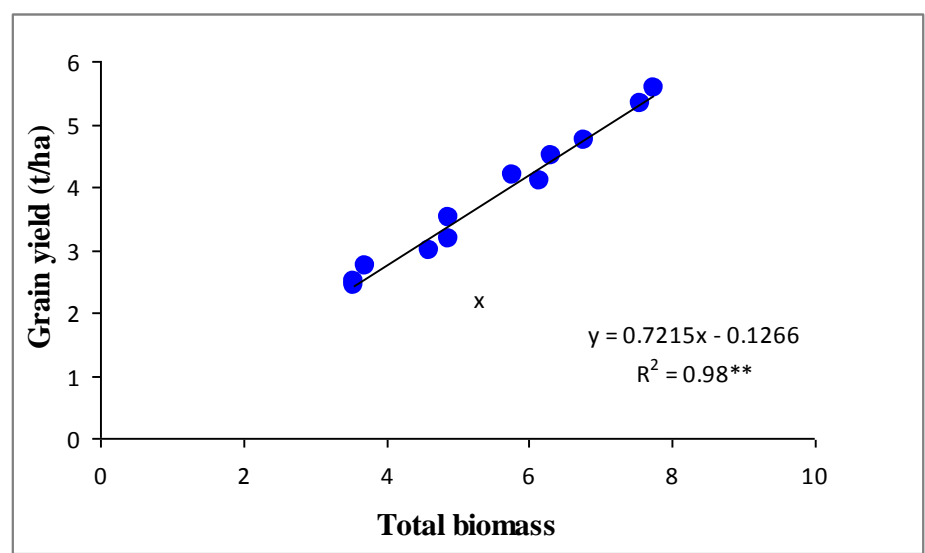

Figure 1. Relationship between grain yield and total biomass of T. Aman rice varieties under different dates of transplanting.
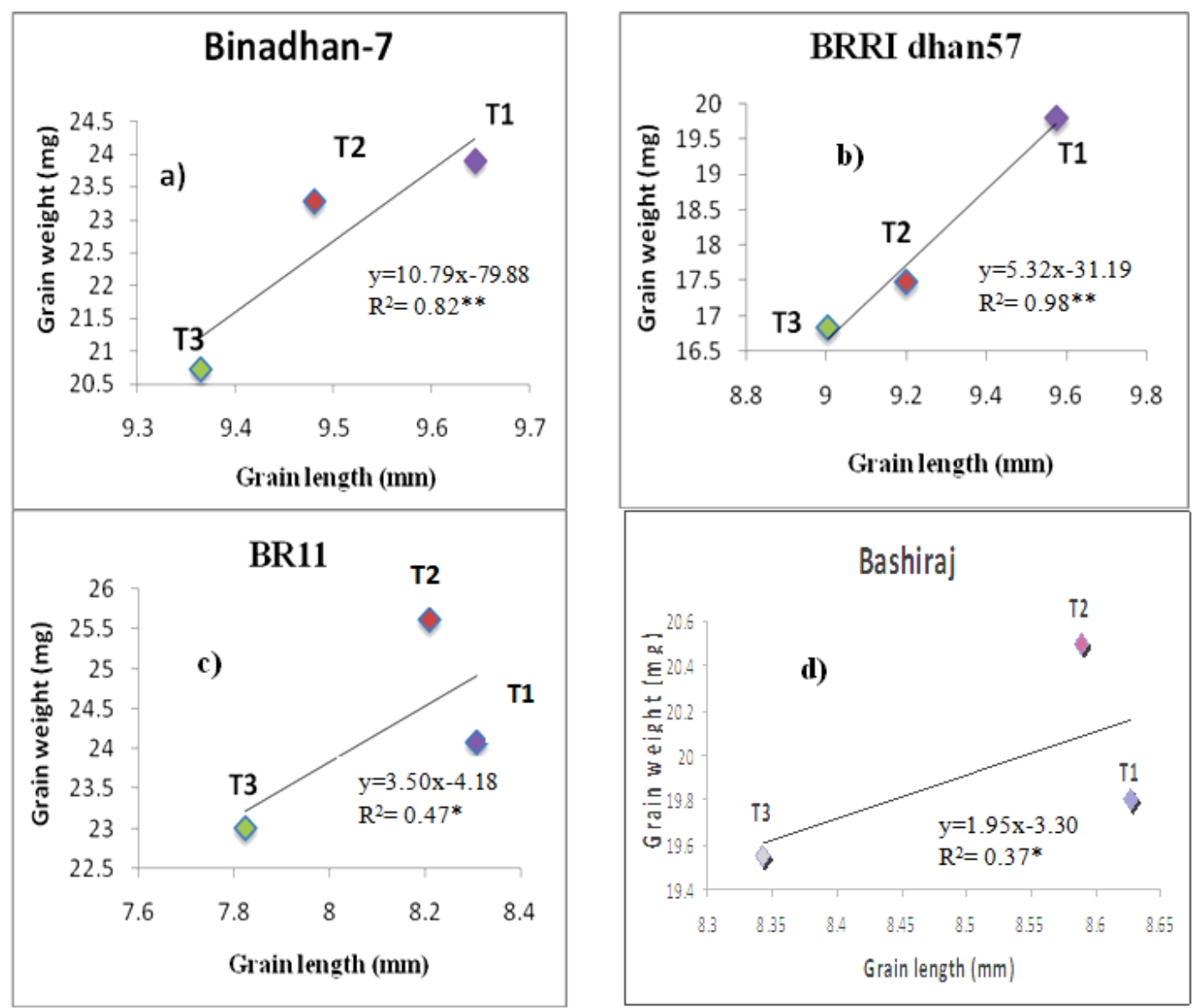

Figure 2. Relationship between individual grain weight and grain length of a) Binadhan-7, b) BRRI dhan57, c) BR11 and d) Bashiraj affected by date of transplanting.

$\mathrm{T}_{1=} 18$ July, $\mathrm{T}_{2}=19$ August, $\mathrm{T}_{3}=18$ September 


\subsection{Grain dimensions}

Grain dimensions mainly include grain length, width and height. Grain length was mostly affected by interaction of date of transplanting and variety.

Grain length showed weakly relationship with the grain weight. Individually Binadhan-7and BRRI dhan57 showed strong relation $\left(\mathrm{R}^{2}=0.82^{* *}\right.$ and $\left.\mathrm{R}^{2}=0.98^{* *}\right)$ with grain weight but the length of BR11 and Bashiraj showed weak relation $\left(R^{2}=0.47^{*}\right.$ and $\left.R^{2}=0.37^{*}\right)$ with grain weight at different date of transplanting (Figure 2 ).

The relationship of grain weight with grain width $\left(\mathrm{T}_{1}: \mathrm{R}^{2}=0.76^{* *}, \mathrm{~T}_{2}: \mathrm{R}^{2}=0.94 * *, \mathrm{~T}_{1}: \mathrm{R}^{2}=0.92^{* *}\right)$, height $\left(\mathrm{T}_{1}: \mathrm{R}^{2}=0.53^{*}, \mathrm{~T}_{2}: \mathrm{R}^{2}=0.99^{* *}, \mathrm{~T}_{1}: \mathrm{R}^{2}=0.89^{* *}\right)$ and volume $\left(\mathrm{T}_{1}: \mathrm{R}^{2}=0.85^{* *}, \mathrm{~T}_{2}: \mathrm{R}^{2}=0.98^{* *}, \mathrm{~T}_{1}: \mathrm{R}^{2}=0.97 * *\right)$ showed positive and moderately strong relationship at different date of transplanting (Figure 3 ).
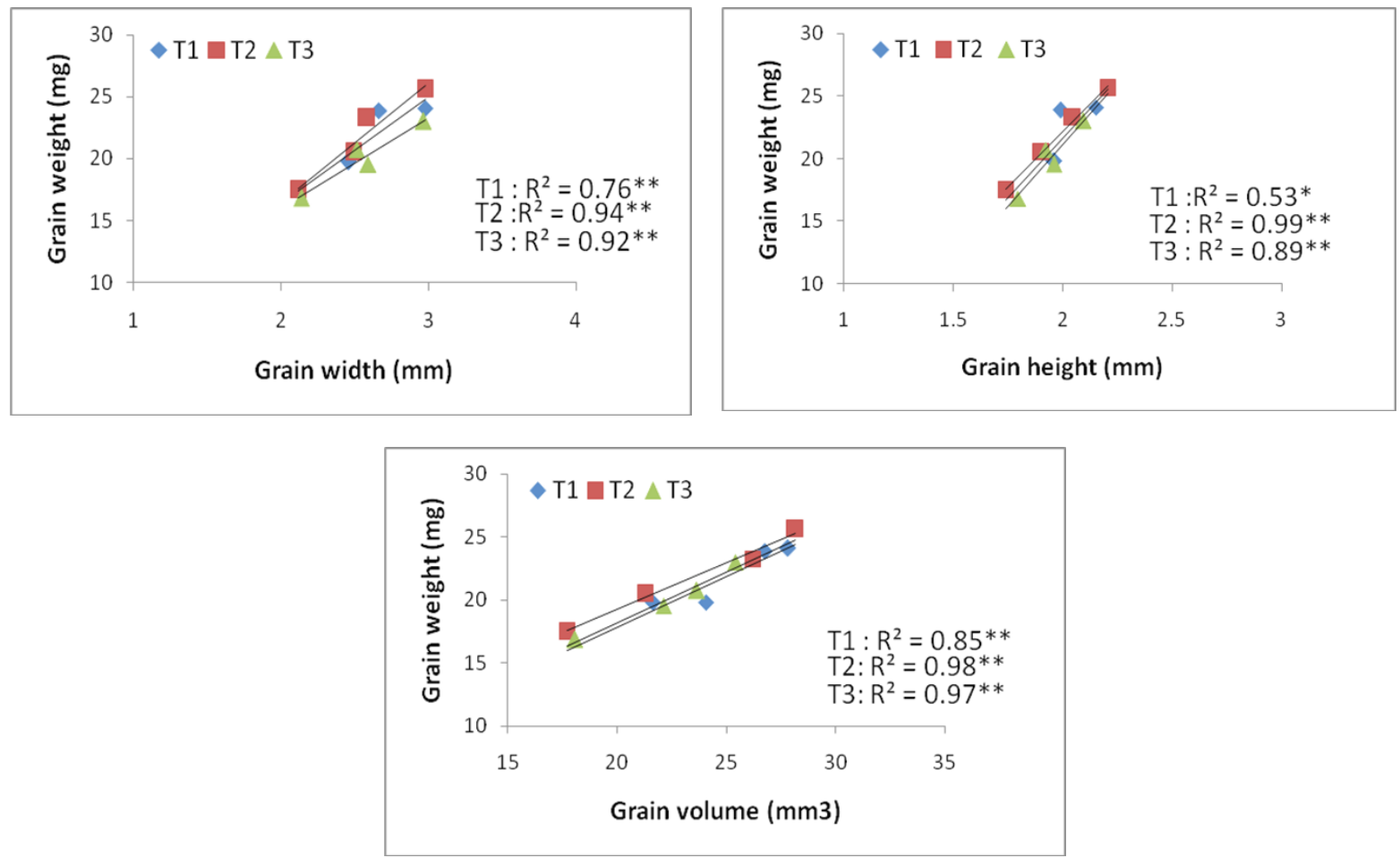

Figure 3. Relationship between individual grain weight and grain width, height and volume affected by variety and date of transplanting.

$\mathrm{T}_{1=} 18$ July, $\mathrm{T}_{2}=19$ August, $\mathrm{T}_{3}=18$ September

\section{Conclusions}

From the above discussion, it may be concluded that the optimum time for transplanting Aman rice ranges between 18 July-19 August. But the growth, yield and yield contributing characters were highest for the varieties when transplanted at 19 August, specially for BR11, yield was drastically reduced then at 18 September. The yield of Binadhan-7was not reduced considerably compared with other varieties. Hence, the present study suggests that the varieties under this study may preferably be planted around 19 August. However, for late transplanting up to 18 September Binadhan-7 may be used for obtaining better yield under AEZ-9 in Aman season. But studies at different agro-ecological zones are needed to arrive at a definite conclusion.

\section{Conflict of interest}

None to declare.

\section{References}

Ali AA, Abou Khalifa and IM El-Rewainy, 2012. Study some physiological characters, yield and yield component for five new rice varieties under different sowing dates. Advances in Applied Science Research, 2012, 3: 440-445.

Anjuman S, 2012. Effect of cultivar and source of phosphorous on the performance of transplant aman rice. M.S. Thesis, Department of Agronomy, Bangladesh Agricultural University, Mymensingh, p. 31.

BBS (Bangladesh Bureau of Statistics), 2011. Monthly Statistical Bulletin, Statistics division Ministry of Planning Government of the Peoples Republic of Bangladesh. pp. 32-37. 
BRRI, 1989. Annual report for 1988, Plant Physiology Division, Bangladesh Rice Research Institute, Joydebpur, Gazipur, Bangladesh, p. 59.

Oteng-Darko P, N Kyei-Baffour and E Ofori , 2013. Yield of rice as affected by transplanting dates and plant spacing under climate change simulations. Wudpecker Journal of Agricultural Research, 2: 55 - 63.

FAO (Food and Agriculture Organization), 2011. FAO Production Year Book, Food and Agriculture Organization of the United Nations, Rome, Italy, 45: 72-73.

Hasan AK, Jaime Herrera, Carolina Lizana and Danie Calderini, 2011. Carpel weight, grain length and stabilized grain water content are physiological drivers of grain weight determination of wheat. Field Crops Research, 123: 241-247.

Khisha K, 2002. An evaluation of Madagascar system of rice production in aman season with three high potential rice varieties. M.S. Thesis, Department of Agronomy, Bangladesh Agricultural University, Mymensingh. pp. 36-63.

Lin LH and WR Wu, 2003. Mapping of QTLs underlying grain shape and grain weight in rice. Mol. Plant Bred, 1: $337-342$.

Miralles DJ, DF Calderini, KP Pomar and A D'Ambrogio, 1998. Dwarfing genes and cell dimensions in different organs of wheat. J. Exp. Bot. 49: 1119-1127.

Pandey N, Verma, AK and RS Tripathi, 2001. Effect of planting time and nitrogenon tillering pattern, dry matter accumulation and grain yield of hybrid rice (Oryza sativa). Indian J. Agril. Sci., 71: 337-338.

Saha R, 2013. Study of agronomic efficiency and recovery efficiency of Urea Super Granule on transplant aman rice. M.S. Thesis, Department of Agronomy, Bangladesh Agricultural University, Mymensingh, p. 54.

Tamanna A, 2007. Effect of date of planting on the growth and performance of four varieties of fine rice. M.S. Thesis, Department of Agronomy, Bangladesh Agricultural University, Mymensingh, p. 42.

Yoshida S, 1981. Fundamentals of rice crop science, International Rice Research Institute, Los Banos Laguna, Philippines, p. 267.

Zhang QF, 2007. Strategies for developing Green Super Rice. Proc. Natl. Acad. Sci. USA. 104: 16402-16409.

Zhu L, Farooq Shah, Lixiao Nie, Kehui Cui, Tariq Shah, Wei Wu,Yutio Chen, Chang Chen, Kai Wang, Qiang Wang, Yun Lian and Jianliang Huang, 2013. Efficacy of sowing date adjustment as a management strategy to cope with rice (Oryza sativa L.) seed quality deterioration due to elevated temperature. AJCS, 7: 543-549. 